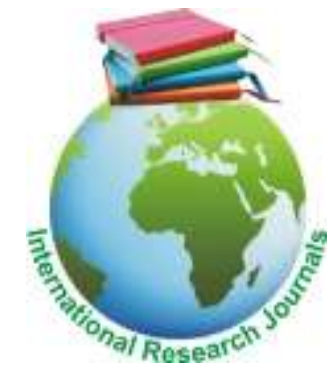

Journal of Research in Economics and International Finance (JREIF) (ISSN: 2315-5671)

Vol. 4(1) pp. 1 - 12, January, 2015

DOI: http://dx.doi.org/10.14303/jrief.2014.044

Available online http://www.interesjournals.org/jreif

Copyright @ 2015 International Research Journals

\title{
The impact of foreign aid on economic growth: Emperical evidence from Ethiopia (1974-2011) using ARDL approach
}

\author{
Prof Haile Girma \\ Department of Economics, Aksum University, Ethiopia \\ Author email address: hghailove@gmail.com
}

ABSTRACT

\begin{abstract}
This paper investigates the impact of foreign aid on economic growth in Ethiopia using time series data for the period 1974 to 2011. Following the most recent literatures, the paper examines whether aid effectiveness is conditional on stable macroeconomic policy environment using the Autoregressive Distributed Lag (ARDL) approach to co-integration proposed by Pesaran and Shin [1997]. Results provide that the negative coefficient of separate foreign aid in regression model shows aid has negative impact on economic growth, but the positive coefficient of aid policy index interaction shows that aid has positively contributed to economic growth in Ethiopia if supplemented with stable macroeconomic policy environment.
\end{abstract}

Keywords: Foreign Aid, Macroeconomic policies, Economic Growth, Ethiopia, ARDL

\section{INTRODUCTION}

Developing countries are characterized by resource starved economies, specifically capital-related. Capital to boost economic growth and welfare is largely inadequate domestically, which consequently warrants the need for external capital. The only external capital readily available to support development undertakings have to come from foreign aid. It began in the late 1940's with the purpose of reconstructing the war-torn economy of Western Europe.

African economies have received large inflow of foreign aid after 1950s. In Ethiopia during the three fiveyear plan period (1957-1973), 25 percent of the required total investment was covered by external public capital. Similarly, during the post revolution period, 37 percent of the total annual campaign of $1979-83$ was financed by foreign aid (Tolessa 2001). Besides, foreign aid covered $23.2 \%$ of total revenue in $2010 / 11$ fiscal year (National Bank of Ethiopia annual report, 2010/11). This shows that foreign aid has been playing the great role in Ethiopia's economy since 1950s.

\section{Statement of the problem}

There is significant increase in foreign inflows, but the economic growth achieved by many Sub Saharan African countries has not been satisfactory. Thus, the actual role of foreign capital inflow has been an area of controversy.

Ethiopia has been one of the major recipients of international aid. It is evident that despite notable donor intervention in the country's economy, less economic growth and poverty remain inherent for many years. Despite this paradoxical scenario, there are few researches capturing the attention of assessing the effectiveness of aid in such a country in order to find out whether aid has been effective, or whether, in fact, the persistent poverty in such an aid-dependent country is not the result of the ineffectiveness of aid. So far done studies are controversial. The study by Abeba S (2002) shows that aid has negative impact on economic growth of Ethiopia while the study by Tasew T (2010) and Yohannes (2011) found that aid has positive impact on 
economic growth of Ethiopia. The current study used new methodology with latest and detailed data to examine the impact of foreign aid on economic growth of Ethiopia (i.e. ARDL).

\section{Objectives}

The general objective of the study is to investigate the impact of foreign aid on economic growth in Ethiopia from 1974 to 2011 using ARDL approach.

\section{Specific Objectives}

- To determine the magnitude and direction of impact of foreign aid on economic growth.

- To find out whether the impact of foreign aid on economic growth of Ethiopia depends on macroeconomic policy environment or not.

\section{Hypothesis to be tested}

- Foreign aid positively affects Ethiopia's Economic Growth.

- The effectiveness of foreign aid on economic growth of Ethiopia depends on macroeconomic policy environment and it has positive contribution to economic growth in this case.

\section{Scope of the study}

The study used time series data from 1974-2011 for Ethiopia. This is because; several country-specific factors may induce apparent differences in the effect of aid on growth, but these factors cannot be fully controlled for in cross-country regressions (especially if effectively unobservable); the classical omitted variables problem. Panel estimation can account for unobserved countryspecific effects, but the homogeneous panel estimators used in the aid literature produce inconsistent and potentially misleading estimates of the average values of the parameters in dynamic models when the slope coefficients differ across cross-section units (e.g., Pesaran and Smith, 1995).

Cross-country analysis is an approach in which each country is treated as sample point assuming that the impact of foreign inflow is constant across countries that is the same in all LDCs. However, the role of external assistance differs greatly from country to country. Furthermore, cross-country analysis assumes that countries are homogenous in terms of economic structure and policy reactions. However, these countries differ significantly on domestic policy measures, economic, political, cultural and social structures. Thus, it is obviously difficult to conclude and recommend policy based on the cross-country .That is, these factors affect the impact of foreign aid differently in different countries. Thus, the study area is limited to single country, Ethiopia. The selection of the series dependence on the availability of data required for the study.

\section{Significance of the study}

In Ethiopia, the number of studies conducted so far on the impact of foreign aid on economic growth is limited in number, in which further study is required. Therefore this study will help in filling knowledge gap in such area. As commonly known aid is a back bone of the Ethiopian economy, therefore the expected outcome from this study could also be useful in improving policy design, institutional setup, implementation, monitoring and evaluation of foreign aid. Besides, it can evoke further study in the area.

\section{LITERATURE REVIEW}

\section{THEORETICAL LITERATURE}

\section{Definition and Basic concepts}

There are various conceptions of foreign aid. The Development Assistance Committee of the Organization for Economic Cooperation and Development (OECD) views it as official development assistance; consisting of grants or loans that one government or multilateral organization gives to a developing country to promote economic development and social welfare. Ekiring (2000) (as cited by Inanga Eno L. and Mandah E. (2008)) conceptualizes foreign aid as an international transfer of capital, goods, or services for the benefit of other nations. Such aid, in her view, is offered in several forms: Capital transfers, in cash or kind, either as grants or loans, Technical assistance and training, usually as grants in the form of human resources and technical equipment, and Military assistance in the form of either equipment or training advisors.

The broad conception of aid as development finance combines official assistance with other official flows. According to World Bank official development assistance and official development finance are two different concepts. That is official development which consists of grants plus concessional loan that have at least a 25 percent grant component is the subset of official development finance (World Bank, 1998). A loan is considered sufficiently concessional to be included in ODA if it has a grant element of at least $25 \%$, calculated at a $10 \%$ discount rate. Broadly speaking ODA includes the costs to the donor of project and program aid, technical co-operation, forgiveness of debts not already reported as ODA, food and emergency aid, and associated administrative expenses. 


\section{Motives and Objectives of Foreign Aid}

The Historical beginning of Foreign aid is related to Marshall Plan which marks the beginnings of the United States aid program. It has been regarded as a model of successful aid and development effort. The success of Marshal Plan helped motivate the United States and other developed countries to provide LDC's with development aid. External resources can play a crucial role in supplementing domestic resources in order to relieve savings or exchange bottlenecks in LDCs. This is the theory of two gap analysis of foreign aid. Assuming LDC's have complementary domestic resources that allow them to undertake new investment projects, then foreign aid will overcome the foreign exchange constraint and raise the rate of economic growth. If LDC's have underutilized resources due to balance of payments constraints then aid disbursement will help them to fully utilize their resources.

The economic objectives of foreign aid are poverty reduction and increasing savings, investment and rate of growth of GNP in developing countries. However, in many cases donor motives for giving aid and recipient motives for accepting it conflict with the economic objectives of foreign aid. According to Todaro (1989) there is no historical evidence that over large periods of time donor country assist others without expecting some corresponding benefits (political, economic, military) in return. This leads to the non-achievement of objectives of foreign aid in many cases.

\section{Economic Impact of Foreign Aid}

The general issue of concern for a number of studies conducted in recent past has been to find a correlation between aid and growth and whether this growth depends on the policy environment. The finding of Sogge and David (2002) states there has been various outcomes of foreign aid on economic growth. They argue that most studies show that where aid has dominated, pride and ambition have given way to dependence and deference, and where it has been targeted, public management and services have either decayed or collapsed, poverty and inequality have worsened, and insecurity has prevailed. He cites Rwanda as an example where many developed countries helped to position the country at the edge of the abyss of genocide - only to disclaim any responsibility in the aftermath. With a few exceptions, (Korea, Botswana and Honduras) where aid has had a significant impact on poverty reduction, improved social services and competent public institutions, in a much larger number of countries (Cuba, Zambia, Democratic Republic of Congo, Haiti, Sierra Leone, Somalia) western aid has played minor role in building efficient public sector and in lifting millions out of poverty. In some cases, major recipients of aid are today collapsed states (e.g. Congo Democratic Republic, Sierra Leone, Somalia).

One of the best-known attempts to assess the impact of aid on growth is by Burnside and Dollar (2000). The study shows that aid has positive effects on growth in the good policy environment, while it does not work in a distorted environment. Good policy environments, according to Burnside and Dollar, are those that are open to trade, have low inflation rates, good share of the budget surplus in relation to GDP (lower budget deficit) and balanced government consumption in GDP. They further argue that there appears to be no systematic impact from aid on policy. For example, in Ghana, good policies were rewarded, while in the case of Zambia, aid increased between 1970 and 1993, while policies deteriorated throughout the period. Burnside and Dollar thus found that aid significantly increased growth in good policy environments as measured by a composite measure of macroeconomic policies, had no effect in average environments, and was actually damaging in bad policy environments.

\section{Determinants of economic growth (some consideration)}

The neo-classical Solow model explains economic growth as resulting from the combination of two elements, namely Capital and Labor. Now the question arises as to how much of the output growth can be attributed to other factors apart from capital and labor. To answer this question, Solow decomposes the growth in output into three components, each identifiable as contribution of one factor of production, that is labor, capital and total factor Productivity. This type of measurement of total factor productivity is still often referred to as the Solow residual. The term residual is appropriate because the estimate present the part of measured GDP growth that is not accounted for by the weighted-average measured growth of the factors of production (capital and labor). To account for this, Solow used the Cobb-Douglas production function as follows:

$Y=f(A, L, K)$

1

Using Cobb-Douglas production function, Solow stated the following equation

$Y=A K^{\alpha} L^{1-\Phi}$

From this, Solow defined his other factor (total factor productivity) to be technology. Solow acknowledged the convenience of the Cobb-Douglas production function because it exhibits constant returns to scale which is consistent with his model. We should note that the variable $A$ is not constant but varies with different production functions based on the factors studied. Different authors have used different factors to account for the total factor productivity. In the following paragraph 
we review one as example.

In accounting for the determinants of Morocco's economic growth, Mansouri (2005) as cited in Antwi Baafi J. (2010) used the aggregate production function model. $\mathrm{He}$ used the aggregate production of the following general form:

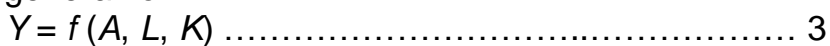

Where, $Y$ is real GDP, $A$ is total factor productivity, and $L$ and $K$ stand for labor and capital inputs respectively. Mansouri (2005) argued that $A$ is determined by economic factors. He argued that in the case of Morocco, FDI and FDI interacted with trade openness (TR) are the vehicle through which technology travels. Therefore, he wrote:

$A=g\left(F D I, F D I{ }^{*} T R\right) \ldots \ldots \ldots \ldots \ldots \ldots \ldots \ldots \ldots \ldots \ldots \ldots$

Substituting (4) into (3), gives:

$Y t=f\left(F D I t, F D I t{ }^{*} T R t, L t, K t\right) \ldots \ldots \ldots \ldots \ldots \ldots \ldots \ldots$

To account for the isolated impact of trade openness on economic growth, Mansouri (2005) introduced TR as an explanatory variable. To take into account of specificities of the Moroccan economy, Mansouri accounted for the impact of drought cycles on economic growth in the particular case of Morocco. Mansouri finally added a proxy for drought (DR) to equation (4), to yield: $Y=G\left(F D I t, T R t, F D I{ }^{*} T R t, L t, K t, D R t\right) \ldots \ldots \ldots \ldots \ldots$ where $D R$ is a proxy for drought, is the inverse of the cereal yield per hectare. The operational model that was finally selected by Mansouri (2005) to explain Moroccan growth is:

$\operatorname{Ln} Y=\beta 0+\beta 1 \ln F D I t+\beta 2 \operatorname{lnTRt}+\beta 3 \ln F D I^{*} T R t+\beta 4 \ln L+\beta 5 \ln +\beta$ $6 \operatorname{lnDRt}+\xi \mathrm{t}$

Other important determinants of growth (positively or negatively) include government consumption expenditure, taxes, population growth, and measures of rule of law, governance, inflation and democracy. In a single country study, the time series approach cannot incorporate all these factors; some are not measured annually, some change very slow over time (and would thus be poor at explaining annual growth which can vary significantly) and there is simply a limit to the number of variables that can feasibly be included. Hence the focus of the current paper is only a sub-set of factors; within the large literature on growth determinants ;it focused on foreign aid, taking capital, labor force, policy environment, Financial deepening, mean annual rain fall and human capital as control variables (M'Amanja D. and Morrissey O. (2005)) .

\section{The aid-growth relationship}

Theory suggests that foreign aid promotes economic growth by supplementing limited domestic savings as well as foreign exchange constraints of recipient developing countries. From the early literature the study conducted by Chenery H.B. and Strout (1966) which itself has its basis on the Harrod-Domar model of economic growth, has been important in this respect. The HarrodDomar growth model supposedly died long ago. But still today, economists in the International Financial Institutions apply the Harrod-Domar model to calculate short-run investment requirements for a target growth rate. They then calculate a "Financing Gap" between the required investment and available resources and often fill the "Financing Gap" with foreign aid. The Financing Gap Model has two simple predictions: (1) aid will go into investment one for one, and (2) there will be a fixed linear relationship between growth and investment in the short run. The three elements of the Harrod-Domar model are income (growth), investment (savings) and incremental capital-output ratio (ICOR) related in the form:

$\mathrm{g}=\mathrm{I} / \mathrm{ICOR}$

The incremental capital-output ratio (ICOR) represents ratio of additional investment to additional output; ' $g$ ' is the growth rate of the economy; and ' $l$ ' represents investment (which is equated to savings).Hence, with the ICOR remaining constant, the rate of economic growth will be directly determined by the rate of investment. With investment assumed to be equal to savings, this implies that a poor country, with low savings, will have low investment and therefore low growth. It is thus expected that a supplementation of domestic savings by foreign aid will resort to an increase in investment, and hence economic growth. Chenery and Strout (1966) base the first step of this two-gap analysis on the case where resource limits on skills and savings are important, and describe this scenario as 'investment limited growth' where the Harrod-Domar model is taken as the limiting case of no foreign assistance. In the second step, they consider the possibility for attaining self-sustaining growth when the balance-of-payments limit is effective and hence describe this situation as 'trade limited growth'.

\section{Debates On Foreign Aid Impact On Economic Growth}

\section{Anti- Aid Literatures}

Generally speaking, economists and researchers who contribute to the anti-aid literature espouse that aid has no effect on growth and that it may actually undermine it. As early as the 1950s, questions on the effect of aid on economic growth have abounded. Economists like Friedman (1958) and Bauer (1972) called for an end in aid, arguing that it is not a necessary requirement for the economic growth of a country. Both Friedman and Bauer assert that foreign assistance to governments is dangerous because it increases the power of the elite in the recipient governments, leads to corruption and hinders economic growth. In particular, Bauer noted that aid discourages the growth of private sector investments, encourages public sector-led growth (since aid is in fact 
money added to government coffers) thereby limiting growth and inhibiting development.

\section{Pro Aid Literature}

Researchers under this category maintain that the claims of the anti-aid school of thought are only partially correct, that aid can spur growth but its effectiveness decreases as the level of aid infused into the economy increases. In other words, aid has diminishing returns.

Some early studies like Papenek GF (1972) found that aid had a positive impact on growth, hence sparking the debate between among economists and researchers. These analysts believed that aid increases growth by augmenting savings, financing investments, and adding to the capital stock. They argue that aid also helps increase productivity, especially aid in health or education programs. They also consider the transfer of knowledge and technology from rich countries to poor countries as a positive effect. Like the early anti-aid literature, these claims were barely substantiated with empirical research. That there is an absolute positive correlation between aid and growth was more a belief than an actual fact since research at this time was focused on testing a linear relationship between aid and growth.

\section{Qualified View}

The effectiveness or ineffectiveness of foreign aid in spurring growth is on a case to case basis. It is therefore rational to identify the key factors that cause aid to work or not work for growth. The studies under this category may be further grouped into those that identify country specific factors and those that point out donor specific characteristics that provide conducive environment for aid to spur growth.

\section{Empirical literature}

Durbarry et al., (1998) assess the impact of foreign aid on growth for developing countries by using an augmented Fischer-Easterly type model and estimate this using both cross-section and panel data techniques. The results strongly support the view that foreign aid does have some positive impact on growth, conditional on a stable macroeconomic policy environment. They also find that these results vary according to income level, levels of aid allocation and geographical location.

The study by Javid M. and Qayyum A. (2011) examines the effectiveness of aid, focusing on the ongoing debate on the interactive effect of aid and policy on sustainable economic growth. Their empirical analysis is based on the ARDL co-integration approach, using the data for the period 1960 to 2008 . The empirical findings of the study are that foreign aid and real GDP have a negative relationship, while the aid-policy interactive term and real GDP growth have a positive and significant relationship. Interesting results emerge when aid-GDP alone is introduced into the growth equation and has an insignificant positive coefficient in the long run and a negative and weakly significant coefficient in the short run, while the aid policy interactive term has a positive and significant coefficient both in the short run and the long run. When they disaggregate aid in terms of the bilateral and multilateral components, bilateral aid is significantly positive in the short run and multilateral aid is insignificant, while the aid interactive term is positive in both cases. The results strongly support the view that foreign aid does have a positive impact on economic growth in Pakistan, if based on sound macroeconomic policies.

Tsikata tsidi M (1998) analysis reveals that aid's impact on growth still generally remains debatable and insignificant relationships still persist on the basis of the prevalent evidence from empirical literature. The study finds some evidence that aid has had a positively significant impact on economic growth under policy conditions conducive to growth. It should be observed that Tsikata's (1998) meta-analysis follows the publication of the World Bank's report (1998) Assessing Aid, and could not have foreseen the criticism following the findings' by Burnside and Dollar $(1997,2000)$ and some of their World Bank colleagues that aid is effective in contributing to economic growth only under conditions of good policies. In terms of aid's impact on growth via channels of domestic savings and investment, Tsikata (1998) finds that the results were mixed, with some pointing to a significant relationship in countries that succeeded in sustaining the adjustment effort.

Feeny S (2005) investigates the impact of foreign aid on economic growth in Papua New Guinea using timeseries data for the period 1965 to 1999 . He examines whether aid effectiveness is conditional on levels of economic policy and governance using the Autoregressive Distributed Lag (ARDL) approach to cointegration proposed by Pesaran and Shin [1995]. His finding provides that little evidence that aid and its various components have contributed to economic growth in Papua New Guinea. There is some evidence that aid is more effective during periods when the country has undertaken a World Bank Structural Adjustment Program (SAP). An alternative interpretation is that a SAP may be more effective at spurring growth when supported by foreign aid.

\section{Empirical literatures in Ethiopia}

In Ethiopia also some researchers tried to investigate the impact of foreign aid on economic growth. Jifar T. (2002) has tried to address the effect of foreign aid on public spending with particular reference to the case of aid fungibility in Ethiopia. The analysis was done using OLS 
estimation. In estimating the short run impact, he employed Error Correction Model. The estimated result in education and agriculture sectors were marked by nonfungiblity in which case the sectoral aid impact on sectoral spending have crowding in effect. However, for transport and communication and construction sector, aid fungiblity seems to exist which means that there is crowding out effect. In this case, the sectoral aid impact on the sectors spending is negative. For nondevelopmental expenditure, aid is found to be significantly affecting debt servicing expenditure but insignificant for general service and defense expenditures.

Tasew T (2010) examined the impact of foreign aid on investment and economic growth in Ethiopia over the period 1970 to 2009 using multivariate co-integration analysis. The empirical result from the investment equation shows that aid has a significant positive impact on investment in the long run. On the other hand, volatility of aid by creating uncertainty in the flow of aid has a negative influence on domestic capital formation activity. Foreign aid is effective in enhancing growth. However, the aid-policy interaction term has produced a significant negative effect on growth implying that bad policies can constrain aid effectiveness. The growth equation further revealed that rainfall variability has a significant negative impact on economic growth as the economy. His study indicated also that the country has no problem of capacity constraint as to the flow of foreign aid.

Yohannes B (2011) has examined the impact of foreign aid on economic growth and the Transmission mechanisms (i.e. investment, import and government consumption expenditure) of Ethiopia using Johansson maximum likelihood approach over the period of 1970/1 to 2008/9. The cointegration test result indicates the existence of long run relationship among the variables entered in all models. According to him in the long run foreign aid has a positive and significant impact on growth through its significant contribution to investment and import. However, the dynamic short runs model points out that aid to have a significant impact on growth it has to be assisted by good monetary, fiscal and trade policy. In addition, in the short run aid has significant impact on government consumption expenditure, which confirms the existence of aid fungibility.

His study also confirms the existence of debt overhang problem in the Ethiopian economy. He concluded that Aid can enhance growth by financing the three gaps. However to mitigate the problems with aid fungibility and debt overhang, foreign aid has to be linked to a good policy framework.

\section{Over all Summary from Literatures}

Over the last three decades, countless academics have produced empirical studies focusing on whether aid is effective in harboring economic growth. The subject has been approached from many different angles. Some studies are based at the micro level; others use a HarrodDomar inspired model, for instance Abeba S (2002). Improved access to data and developments in empirical methods mean older papers have been superseded by more modern studies. This study revolves around the work carried out in the third generation which was developed by Hansen and Tarp (2000) -Third Generation papers use larger data sets, modernized growth models and improved empirical methods.

Hansen and Tarp (1999) argue that aid has an optimal level, and if this level is reached, additional aid will have a negative effect-carrying capacity constraints which means that at a certain level of aid, the resources cannot be fully absorbed (lack of infrastructure), which result in counter productivity. Hadjimichaels, et al., (1995) and Hansen and Tarp (1999) produce a figure of carrying capacity constraint to be $25 \%$. That is if aid as percentage of GDP is greater than 25 percent aid growth relationship has to be quadric and if it is less than $25 \%$ aid-growth relationship should be linear ( both papers are cited in Hansen H. and Tarp F. (2000)).

Durbarry R. et al., (1998) find robust evidence, from a variety of samples and alternative econometric techniques, (using an augmented Fischer-Easterly type model and estimate this using both cross-section and panel data techniques) that greater foreign aid inflows have a beneficial effect on LDC growth, conditional on a stable macroeconomic policy environment in those countries. Their results also suggest, however, that there is an optimal aid allocation in terms of growth effects: while low amounts of aid do not appear to generate faster growth, very high aid/GDP ratios are also associated with slower growth. Their results also consistently put this optimum at around $40-45 \%$. Their results suggest negligible growth effects of foreign aid (small and statistically insignificant parameters) in low income countries and those receiving only small amounts of aid (less than about $13 \%$ of their GDP).

Thus, following these papers this study uses linear aid-growth relationship which makes it different from Tasew T. (2010) and Yohannes B. (2011) which used quadratic aid-growth relationship. This is because in no any year under study aid as percentage of GDP is greater than 25\% in Ethiopia. Tasew T (2010) himself concluded that Ethiopia has no problem of carrying capacity constraint and as such linear aid-growth equation should be used to see the impact of foreign aid on economic growth.

Burniside and Dollar (2000) build on the ideas put forward by Boone (1996), focusing on how policy interacts with aid to raise growth. The Burnside and Dollar (2000) paper is a milestone in the literature; focusing on the conditions under which aid impacts are maximized rather than studying whether aid works or not. 
Further empirical analysis by Durbarry, et al., (1998) and Easterly (2003) agree that an aid-policy interaction term is important, despite producing different results to Burniside and Dollar (2000).Like these studies this study incorporates aid policy interaction but different from them in that this is country specific study and use new methodology (ARDL approach to co-integration). Hudson and Mosley (2001) mentioned two reasons for the inclusion of the policy variables in regression model. First, there is possibility that countries with a good policy environment grow faster, regardless in the changes of factor of production. Second, there is possibility that in the presence of good policy environment, Credit is translated into investment. However, Hansen and Tarp (2001) described that the role of macroeconomic policy for aid effectiveness is ambiguous.

\section{METHODOLOGY}

\section{Data Sources and methodology}

The necessary data for the paper is collected from various sources such as Ethiopian Economic association (EEA) data base CD Rom 2012, Ministry of finance and Economic Development (MOFED), National Bank of Ethiopia (NBE), Ethiopian Central Statistical Authority (CSA), National Metrology Agency, International Monetary Fund (IMF) database, Penn World Table and World Bank online Data bases.

The method employed in the study is based on recent advancements in the theoretical and empirical aidgrowth relationships. As the data used is time series, various tests such as testing for stationary (unit root test) and co-integration test are performed. The rank of cointegration is determined by using ARDL. The model is estimated by using Ordinary least Square (OLS).

\section{Model specification}

The model to examine the relationships between foreign aid and GDP growth in the paper is derived from neoclassical growth model:

$Y(t)=F[K(t), A(t) L$

and its Cobb-Douglas function:

$$
\begin{aligned}
& \mathrm{F}(\mathrm{K}, \mathrm{AL})=K^{\alpha} A L^{1-\alpha}, 0<\alpha<1 . \\
& \operatorname{LnRGDP_{\mathrm {t}}}=\beta_{1}+
\end{aligned}
$$

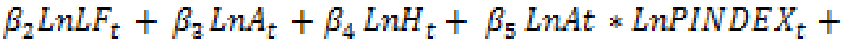

$$
\begin{aligned}
& \beta_{6} \operatorname{LnPINV}_{\mathrm{t}}+\beta_{7} \operatorname{LnMEANR}_{\mathrm{t}}+\beta_{9} \operatorname{Ln} M 2 / \text { RGDP }_{\mathrm{t}}+\xi t
\end{aligned}
$$

(8)

$$
\text { Where, }
$$

- LnRGDPt : natural logarithm of real gross domestic product used as a proxy for national income at year $t$
- LnLFt: natural logarithm of percentage of total labor force to total population ratio taken at year $t$

- LnAt: natural logarithm of percentage of foreign aid to $R G D P$ ratio at year $t$

- LnHt: natural logarithm of the sum of secondary and tertiary gross enrolment ratio used as proxy variable for Human capital at year $t$

- LnAt*Lnpindext : natural logarithm of foreign aid interacted by natural logarithm of policy index at year $\mathrm{t}$

- $\quad$ LnMEANR $_{\mathrm{t}}$ :natural logarithm of mean annual rain fall at year $\mathrm{t}$

- $\quad$ nnM2/RGDP $P_{\mathrm{t}}$ : natural logarithm of broad money supply to RGDP ratio at year $t$ (financial deepening)

- $\quad \beta$ 's are elasticity and $\xi$ is white error term

An ARDL representation of equation 1 will be:

$$
\begin{aligned}
& \Delta L n R G D P_{\mathrm{t}}=\alpha_{0}+\sum_{\mathrm{i}=1}^{\mathrm{n}} \alpha_{1} \Delta L n R G D P_{\mathrm{t}-\mathrm{i}}+\sum_{\mathrm{i}=0}^{n} \alpha_{2} \Delta L n L F_{\mathrm{t}-\mathrm{i}}+\sum_{\mathrm{i}=0}^{n} \alpha_{\mathrm{n}} \Delta L \eta A_{\mathrm{t}-\mathrm{i}}+\sum_{\mathrm{i}=0}^{n} \alpha_{4} \Delta L \eta H_{\mathrm{t}-\mathrm{i}}
\end{aligned}
$$

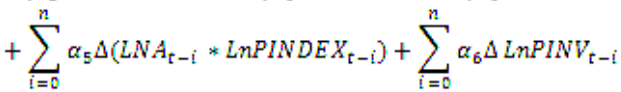

$$
\begin{aligned}
& +\sum_{i=0}^{n} \alpha_{7} \Delta L n M E A N R_{\mathrm{t}-\mathrm{i}}+\sum_{\mathrm{i}=0}^{\mathrm{n}} \alpha_{\mathrm{s}} \Delta L n M 2 / R G D P_{\mathrm{t}}+\beta_{1} \operatorname{LnRGDP_{\mathrm {t}-1}}
\end{aligned}
$$

Where, $\Delta$ denotes the first difference operator; $\alpha 0$ is the drift component, and nt is the usual white noise residuals, $\alpha$ 's are coefficients of short run dynamics and $\beta$ 's are long run relationship.

To investigate the presence of long run relationships among the variables bound test under Pesaran, et al., (2001) is used which is based on the F-test. It is actually a test of the hypothesis of no co-integration among the variables against the existence or presence of cointegration among the variables which is denoted as:

$H_{0}: \beta_{1}=\beta_{2}=\beta_{a}=\beta_{4}=\beta_{5}=\beta_{6}=\beta_{7}=\beta_{9}=0$ there is no co-integration among the variables $H_{a}: \beta_{1} \neq \beta_{2} \neq \beta_{a} \neq \beta_{4} \neq \beta_{5} \neq \beta_{6} \neq \beta_{7} \neq \beta_{8} \neq 0$ There is co-integration among variables.

The error correction version of equation 9 will be:

$$
\begin{aligned}
& \Delta L n R G D P_{\mathrm{t}}=\alpha_{0}+\sum_{\mathrm{i}=1}^{n} \alpha_{1} \Delta L n R G D P_{\mathrm{t}-\mathrm{i}}+\sum_{\mathrm{i}=0}^{n} \alpha_{2} \Delta L n L F_{\mathrm{t}-\mathrm{i}}+ \\
& \sum_{\mathrm{i}=0}^{n} \alpha_{\mathrm{a}} \Delta \operatorname{Ln} A_{\mathrm{t}-\mathrm{i}}+\sum_{\mathrm{i}=0}^{\mathrm{n}} \alpha_{4} \Delta \operatorname{Ln} H_{\mathrm{t}-\mathrm{i}}+\sum_{\mathrm{i}=0}^{n} \alpha_{5} \Delta\left(L N A_{\mathrm{t}-\mathrm{i}} * \operatorname{Ln} P I N D E X_{\mathrm{t}-\mathrm{i}}\right)
\end{aligned}
$$

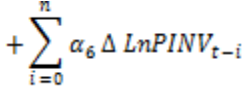

$$
\begin{aligned}
& +\sum_{i=0}^{n} \alpha_{7} \Delta L n M E A N R_{t-i}+\sum_{i=0}^{n} \alpha_{g} \\
& \Delta(\operatorname{LnM2} / R G D P)_{\mathrm{t}-2}+\lambda \mathrm{E} c_{\mathrm{i}-1}+u_{\mathrm{t}}
\end{aligned}
$$


Table1. The Results of F-Test for Co-integration

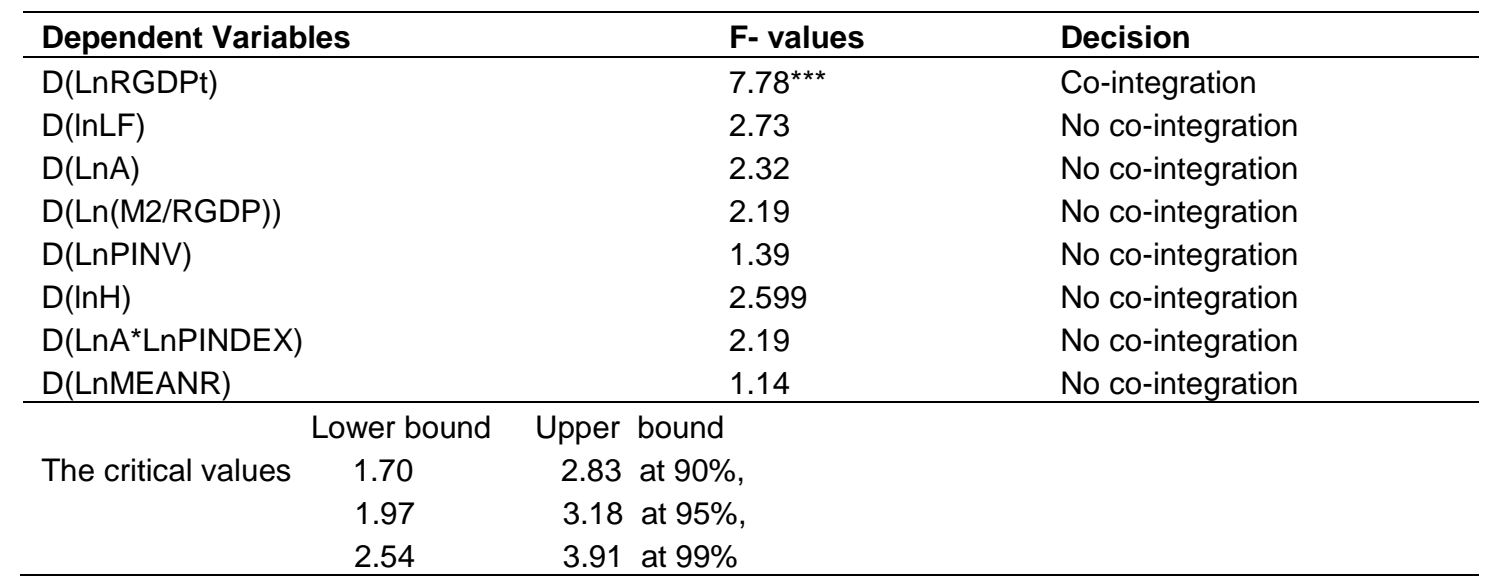

The assumption of only one co-integrating vector is fulfilled that is only $D(L n R G D P)$ is endogenous variable

Table2. Estimated long run coefficients using the ARDL approach $\operatorname{ARDL}(1,0,0,0,0,0,0,1)$ selected based on Akaike information criterion: dependent variable $\operatorname{Ln}(\mathrm{RGDP})$.

\begin{tabular}{lrrc}
\hline Variable & Coefficients & t-ratio & Probability \\
\hline LnPINV & 0.075474 & 1.5206 & 0.140 \\
InLF & -1.6017 & -3.1581 & 0.004 \\
LnA & -0.65813 & -3.2272 & 0.003 \\
LnMEANR & 0.57904 & 1.7894 & 0.084 \\
Ln(M2/RGDP) & 0.15630 & 2.7716 & 0.010 \\
InH & 2.7246 & 5.9616 & 0.000 \\
LnA ${ }^{*}$ LnPINDEX & 0.20526 & 3.5549 & 0.001 \\
\hline
\end{tabular}

Note: ${ }^{*}=$ significant at $10 \%,{ }^{* *}=$ significant at $5 \%$ and ${ }^{* * *}$ significant at $1 \%$

Where $\lambda$ is the speed of adjustment parameter and EC is the residuals that are obtained from the estimated cointegration model of equation (9).

\section{RESULTS AND DISCUSSION}

The study is based on the annual time series data from 1974 to 2011. The total number of observation is 38 . Data analysis was performed by Eviews 5 and micro fit 5 . Before proceeding with the ARDL bounds test, the unit root test was done. This is to ensure that the variables are not I(2) stationary so as to avoid spurious results because the bounds test is based on the assumption that the variables are $\mathrm{I}(0)$ or $\mathrm{I}(1)$. Only mean annual rain fall was found stationary at level, while other variables are stationary after first difference. ARDL co-integration test, assumed that only one long run relationship exists between the dependent variable and the exogenous variables (Pesaran S. and Smith, 2001, assumption 3). To test whether this is really appropriate in the current application, the entire variables were changed to dependent variable in order to compute the F-statistic for the respective joint significance in the ARDL models (Narayan P, 2004). Since AIC tends to have practical performance advantages over BIC (Burnham KP and Anderson DR. 2002; 2004) the lag length is selected by AIC (table1).

\section{Long run and Short run Coefficients}

Once co-integration is established, the conditional ARDL long-run model for $\operatorname{Ln}(\mathrm{RGDP})$ can be estimated and the result is presented in table 2 .

Foreign aid taken separately has negative impact on RGDP, One percent change of foreign aid-RGDP ratio results in $-0.658 \%$ in RGDP change. Javid $M$ and Qayyum A (2011) mentioned that Donor's conditionality, poor governance, tied aid, kickbacks paid to the foreigner contractor and weak state institution might be the causes of failure of contribution of foreign aid in development process of the economy. Easterly and Pfutze (2008) as 
Table3. Estimated coefficient of short run dynamics (error correction)

ARDL $(1,0,0,0,0,0,0,1)$ selected based on Akaike Information Criterion, dependent variable is $D(R G D P)$

\begin{tabular}{|c|c|c|c|}
\hline Variables & Coefficients & t-statistics & Probability \\
\hline $\mathrm{D}(\mathrm{LnPINV})$ & 0.032377 & 1.5740 & 0.126 \\
\hline $\mathrm{D}(\mathrm{LnLF})$ & -0.68712 & -2.8868 & 0.007 \\
\hline $\mathrm{D}(\operatorname{LnA})$ & -0.28233 & 3.3459 & 0.002 \\
\hline $\mathrm{D}($ LnMEANR $)$ & 0.089399 & 0.72749 & 0.473 \\
\hline $\mathrm{D}(\mathrm{LnH})$ & 1.1688 & 3.4554 & 0.002 \\
\hline $\mathrm{D}\left(\operatorname{Ln} A^{*} \operatorname{LnPINDEX}\right)$ & 0.088054 & 3.4035 & 0.002 \\
\hline D(M2/RGDP) & 0.067051 & 2.7999 & 0.009 \\
\hline $\operatorname{ecm}(-1)$ & -0.42898 & -4.1476 & 0.000 \\
\hline
\end{tabular}

Note: ${ }^{*}=$ significant at $10 \%,{ }^{* *}=$ significant at $5 \%$ and ${ }^{* \star *}$ significant at $1 \%$

Table4. Diagnostic tests for long run and short run model

\begin{tabular}{lrrrr}
\hline & & Short run & Long run \\
\hline Tests & $\chi^{2}$ statistics & Probability & $\chi^{2}$ statistics & Probability \\
Breush-Godfrey serial Correlation LM & 3.211 & 0.2007 & 4.66 & 0.097 \\
White Heteroskedasticity test & 23.54 & 0.26 & 20.87 & 0.28 \\
Jarque Bera Normality Test & 1.35 & 0.507 & 0.033 & 0.98 \\
Ramsey Reset Log Likely hood Ratio & 0.51 & 0.47 & 3.063 & 0.0918 \\
\hline
\end{tabular}

cited in Williamson CR, (2009) highlight three ineffective aid channels: tied aid, food aid, and technical assistance. These might also be true in Ethiopia (table3).

The coefficient on the lagged error-correction term is highly significant at one percent level of significance with the expected sign, which confirms the result of the bounds test for co-integration. Its value is estimated to 0.429 which implies that approximately $0.429 \%$ of disequilibria from the previous year's shock converge back to the long-run equilibrium in the current year. Foreign aid and RGDP have negative relationship; the one percentage change in percentage of foreign aid RGDP ratio causes RGDP to be changed by $0.282 \%$, other variables remaining constant. When aid is interacted with policy index it has got positive coefficient and highly significant. This shows aid is effective when supplemented with good macro policy environment. This positive result is similar to that of Yohannes B (2011) in Ethiopia.

The Long run equation is:

$$
\begin{aligned}
& R G D P=\frac{0.075474^{*} \operatorname{LnPINV}}{(0.0496)}-\frac{1.6017^{*} \operatorname{LnLF}}{(0.5071)}-\frac{0.65813^{*} \operatorname{LnA}}{(0.2393)} \\
& +\frac{2.7246^{*} \mathrm{LnH}}{(0.4570)}+\frac{0.20526^{*}\left(\mathrm{LnA}^{*} \operatorname{lnPINDEX}\right)}{(0.057)} \\
& +\frac{0.15630^{*} \mathrm{Ln}(\mathrm{M} 2 / \mathrm{RGDP})}{(0.0564)}+\frac{0.57904^{*} \mathrm{LnMEANR}}{(0.3236)}+\underline{\mathrm{ecm}}
\end{aligned}
$$

Figures in parentheses are standard error
As can be seen from table 4 both long run and short run model pass all the diagnostic tests against serial correlation Breusch-Godfrey test, heteroscedasticity (White Heteroskedasticity Test), and normality of errors (Jarque-Bera test). The Ramsey RESET test also suggests that the model is well specified.

\section{Stability Test}

The stability of the long-run coefficient is tested by the short-run dynamics. Once the Error correction model has been estimated the cumulative sum of recursive residuals (CUSUM) and the CUSUM of square (CUSUMSQ) is applied to assess the parameter stability (Pesaran, 1997). The results indicate the absence of any instability of the coefficients because the plot of the CUSUM statistic and the CUSUM of square (CUSUMSQ) fall inside the critical bounds of the $5 \%$ confidence interval of parameter stability.

\section{Multi-collinearity test}

Multicollinearity is a question of degree and not of kind. The meaningful distinction is not between the presence and the absence of multicollinearity, but between its various degrees. Since multicollinearity refers to the condition of the explanatory variables that are assumed to be non-stochastic, it is a feature of the sample and not 
of the population. Therefore, we do not "test for multicollinearity" but can, if we wish, measure its degree in any particular sample. Since multicollinearity is essentially a sample phenomenon, arising out of the largely non experimental data collected in most social sciences, we do not have one unique method of detecting it or measuring its strength. What is available is some rules of thumb, some informal and some formal, but rules of thumb all the same Gujarati D (2003). The one with less criticism of these rules is High $R 2$ but few significant $t$ ratios.

\section{High $R 2$ but few significant $t$ ratios}

This is the "classic" symptom of multicollinearity. If $R 2$ is high, say, in excess of 0.8 , the $F$ test in most cases rejects the hypothesis that the partial slope coefficients are simultaneously equal to zero, but the individual $t$ tests will show that none or very few of the partial slope coefficients are statistically different from zero. Although this diagnostic is sensible, its disadvantage is that "it is too strong in the sense that multicollinearity is considered as harmful only when all of the influences of the explanatory variables on $Y$ cannot be disentangled.

In this study though R-squared is found high only private investment is insignificant. Since strong multicollinearity makes the standard error inflated almost all variables become insignificant. In this study, however, almost all variables are significant showing that there is no series multicollinearity problem in the model.

\section{CONCLUSION}

In this study, based on theories and literatures the equations for growth, has been identified and estimated using the ARDL model. In line with the main objective of the study first a relationship between foreign aid and economic growth was tested. Similar to findings of Abeba $S$ (2002) foreign aid has negative contribution on RGDP growth both in short run and long run period in Ethiopia disproving the first hypothesis of the study. In the longrun and short run on average, a one percentage increase in the aid-to-RGDP ratio leads to a decrease in RGDP growth by about $0.65 \%$ and $0.28 \%$ respectively, other variables being constant. Foreign aid interacted with policy index has positive coefficient showing that the effectiveness of aid depends on macroeconomic policy. This result is also similar to that of Yohannes B (2011).

\section{ACKNOWLEDGEMENT}

First of all I would like to thank the almighty God (and his mother Saint Virgin Mary) for His guidance and love and for giving me the opportunity to follow my study. Next I would like to forward the deepest of my appreciation and gratitude to my advisor Abebe Habte (PhD) for his patience and constructive advice throughout the course of the thesis. Not only did he help me with invaluable advice, I have also learned a lot from him. The brotherly treatment he accorded me has served as an inspiration for the completion of this study.

I would also like to thank Axum University for its sponsorship to follow my Master program. My sincere thanks also go to my family for their lovely and tireless moral support. Lastly, but not least, I am grateful to my friends, classmates and individuals in different ministries who have helped me while I was writing this thesis.

\section{REFERENCES}

Abeba S (2002), "macroeconomic impacts of external assistance in Ethiopia" A thesis submitted to the School of Graduate Studies of Addis Ababa University in Partial fulfillment of the requirements for the Degree of Master of Science in Economic Policy Analysis in Department of Economics.

Adugna L (2004), "Anatomy of foreign aid to Ethiopia: 1960-2003", university of Massachusetts Boston.

African development bank group (2000), "Ethiopia's structural adjustment programme project performance evaluation report" operations evaluation department

African economic outlook report (2012), "Ethiopia Full PDF Country Note"

Alemayehu G ( 2005), "The Political Economy of Growth in Ethiopia” Chapter 4 of volume 2 Addis Ababa University

Alemayehu G and Kibrom T (2011), "Official Development Assistance (Aid) and Its Effectiveness in Ethiopia", Institute of African Economic Studies.

Art C. (2009), "On Foreign Aid and Economic Change", the Journal of Private Enterprise 25(1), 2009, 105-123 Rhodes College.

Baafi J (2010), "Ghana's economic growth in perspective: a time series approach to convergence and growth determinants" , Södertörns Högskola Soderteor university Master Thesis

Barros AP, Kim G, Williams E, Nesbitt SW (2004), "Probing orographic controls in the Himalayas during the monsoon using satellite imagery": Natural Hazards and Earth Systems Science. 4: 1-23

Batana MY (2009), "Aid and Poverty in Africa" University of Montreal

Bauer P (1972), "Dissent on development", Cambridge: Harvard University Press.

Bauer P (1991), "The development frontier" essays in applied economics. London: Harvester Wheat sheaf.

Berhanu N, Seid N. (2004) "Determinants of Low Growth in Ethiopia: Beyond Traditional Factors", Proceeding of the 1st International Conference on the Ethiopian Economy.

Boone P (1996), "Politics and the effectiveness of foreign aid", European Econ. Rev. 40: 289-329.

Brautigam DA, Knack S (2004), "Foreign aid, institutions, and governance in Sub-Saharan Africa", Economic Development and Cultural Change, 13:255-285.

Bring J (1994). "How not to find the Relationship between Foreign Aid and Economic Growth", Appl. Econ. Letters. 1: 32-33.

Burnham KP, Anderson DR (2002), "Model Selection and Multi model Inference: A Practical Information", Theoretic Approach (2nd ed.), Springer-Verlag, ISBN 0-387-95364-7.

Burnham KP, Anderson DR (2004), "Multi model inference: understanding $\mathrm{AIC}$ and $\mathrm{BIC}$ in Model Selection" second edition

Burnside C, Dollar D (2000), "Aid, policies, and growth", Ame. Econ. Rev. 90: 847-868

Cashel-Cordo P, Craig SG (1990), "The Public Sector Impact of International Resource Transfers", J. Develop. Econ. 32. 
Chenery HB, Strout A (1966), "Foreign assistance and economic development," Ame. Econ. Rev. 56: 679-733.

Clements Benedict, Sanjeev Gupta, Alexander Pivovarsky, Erwin R. Tiongson (2004). "Foreign Aid: Grants versus Loans, Finance and Development"

Dalgaard CJ, Hansen H, Tarp F (2004), "On the empirics of foreign aid and growth," Econ. J. 114:191-216.

David R (2004), "The Anarchy of Numbers: Aid, Development, and Cross-country Empirics", working paper number i

Dritsakis N (2012), "Demand for money in Hungary: An ARDL Approach" Department of Applied Informatics University of Macedonia Economics and Social Sciences 156 Egnatia Street, 54006 Thessaloniki, Greece

Dollar D, Collier P (2001). "Can the world cut poverty in half? How policy reform and effective aid can meet the international development goals", World Development 29(11): 1787-1802.

Doucouliagos H, Paldam M (2008), "Conditional aid effectiveness: a meta-analysis", J. Int. Develop. 21(7):1582-1601.

Dierk H, Oliver M (2011), "Long-Run Aid Effectiveness" - paper \#144, CSAE Conference 2011, Economic Development in Africa, Oxford, March 20-22

Dowling M, Hiemenz U (1982), "Aid, Savings and Growth in the Asian Region," Economic Office Report Series 3, Asian Development Bank: Manila.

Durbarry Ramesh, Norman Gemmell, David Greenaway (1998), "New Evidence on the Impact of Foreign Aid on Economic Growth", Centre for Research in Economic Development and International Trade, University of Nottingham

Easterly WR, Rebelo ST (1993). "Fiscal Policy and Economic Growth: An Empirical Investigation". J. Monetary Econ. 32(3)

Easterly W (2003). "Can Foreign Aid Buy Growth?" J. Econ. Perspectives. 17(3): 23-48

Ekiring Rachael (2000), "Impact of Foreign Aid on poverty Alleviation in Developing Countries: With an Application to Uganda", Maastricht School of Management, The Netherlands.

FASANYA Ismail O, ONAKOYA Adegbemi BO (2012) "Does Foreign Aid Accelerate Economic Growth?An Empirical Analysis for Nigeria", Int. J. Econ. Fin. Issues

Feeny S (2005), "the Impact of Foreign Aid on Economic Growth in Papua New Guinea", the journal of development studies.

Feeny S, McGillivray M (2008), "Aid allocation to fragile states: absorptive capacity constraints," J. Int. Develop. 20(7):1031-1050.

Frey B, Schneider F (1986), "Competing Models of International Lending Activity" J. Develop. Econ. 20

Friedman M (1958), "Foreign Economic Aid: Means and Objectives", Yale Review. 47

Fosu OE. Magnus FJ (2006) "Bounds Testing Approach to Cointegration : An Examination of Foreign Direct Investment Trade and Growth Relationships", School of Business, Garden City University College, P.O. Box KS 12775, Kumasi, Ghana KNUST School of Business, Kwame Nkrumah University of Science and Technology, Kumasi, Ghana

Gang IN, Khan HA (1991), "Foreign Aid, Taxes and Public Investment", J. Dev. Econ. 34

Getnet A (2009), "A case study on aid effectiveness in Ethiopia, analysis of the health sector aid architecture", Wolfensohn center for development working paper 9

Ghatak S (1986). "An Introduction to Development Economic", Allen and Unwin Ltd. London, P129.

Griffin KB, Enos JL (1970), "Foreign Assistance: Objective and Consequences", Economic Development and Cultural Change. 18:313-327

Gupta KL, Islam MA (1983). "Foreign Capital, Savings and Growth-an International Cross-Section Study", Reidel Publishing Company: Dordrecht.

Hansen H, F Tarp (2000), "Aid effectiveness disputed," J. Int. Develop. 12: $375-398$

Hansen H, Tarp F (2001), "Aid and growth regressions", J. Develop. Econ. 64: 547-570.

Hansen H, Tarp F (2002). "Aid and growth regressions" DERG, University of Copenhagen, Denmark
Harris R, Sollis R (2003). "Applied Time Series Modeling and Forecasting" Durham University

Herzer D, Morrissey O (2004). "Long-Run Aid Effectiveness" CSAE Conference 2011, Economic Development in Africa, Oxford, March 20-22 paper 144

Hudson J, Mosley P (2001), "Aid Policies and Growth: In Search of the Holy Grail”, J. Int. Develop. 13:1023-1038.

Inanga EL, Mandah E (2008). "Foreign Aid Finance and Economic Development: The Case of Two Foreign Aid Financing Agencies in Zambia", Int. Res. J. Fin. Econ. ISSN 1450-2887. 14 :322-358.IMF (2002). "Ethiopia Enhanced Structural Adjustment Facility" Medium-Term Economic and Financial Policy Framework Paper, 1998/99-2000/01

Isham J, Kaufmann D, Pritchett L (1995), "Governance and returns on investment: an empirical investigation", Policy Research Working Paper Number 1550, World Bank, Washington.

Islam A (1992). "Foreign aid and economic growth: An econometric study of Bangladesh," Applied Econ. 24: 541-544

Jensen PS, Paldam M (2003), "Can the New Aid-Growth Models Be Replicated?" Working Paper No.2003-17, Institute for Economics: Aarhus.

Javid M, Qayyum A(2011) "foreign aid and growth nexus in Pakistan: the role of macroeconomic policies", PIDE Working Papers

Jiffar T (2002), "The Impact of Foreign Aid on Public Spending: The Ethiopian Case", Unpublished M.Sc. Thesis, AAU.

Kargbo PM (2012). "impact of foreign aid on economic growth in Sierra Leone", world institute for development economics research centre, Working Paper No. 2012/07 Helsinki, Finland

Karras G (2006), "Foreign aid and long-run economic growth: empirical evidence for a panel of developing countries," J. Int. Develop. 18(7):15-28

Lloyd T, Morrissey O, Rosie R (2001). "Aid, Exports and Growth in Ghana" CREDIT Research Paper 01/01. Nottingham: University of Nottingham.

Mahadeva L, Robinson P (2004). "Unit root testing to help model building", hand book in central banking No.22, Bank of England

M'Amanja D, Morrissey O (2005). "Foreign Aid, Investment and Economic Growth in Kenya: A Time Series Approach", CREDIT Research Paper 06/05. Nottingham: University of Nottingham.

Mbaku JM (1993), "Foreign aid and economic growth in Cameroon", Applied Econ, 25: 1309-1314.

Melaku T (2013) "Can Ethiopia's Economic Growth Sustain without saving?" Addis Abeba chambers of Commerce and sectoral association.

Morrissey O (1990), "The impact of Multilateral and Tied Bilateral aid on the U.K. Economy", J. Int. Develop. 2(1)

Mosley P (1980). "Aid, savings and growth revisited," Oxford Bulletin of Economics and Statistics, 42(2):79-95

Murthy VNR, Ukpolo V, Mbaku JM (1994), "Foreign Aid and Economic Growth in Cameroon: Evidence from Cointegration Tests", Applied Economic Letters. 1(10): 161-3.

Narayan P (2004). "Reformulating Critical Values for the Bounds Fstatistics Approach to Cointegration: An Application to the Tourism Demand Model for Fiji"Monash University Victoria 3800 Australia

Njeru J (2003). "The impact of foreign aid on public expenditure: The case of Kenya" AERC Research Paper No 135. African Economic Research Consortium, Nairobi, Kenya

Papanek GF (1972). "The effect of aid and other resource transfers on savings and growth in less developed countries", The Econ. J. 82 934-950.

Papanek GF (1997). "The effect of aid and other resource transfers on savings and growth in less developed economies", J. Pol. Economy, 82: 120-30.

Pesaran MH, Shin Y (1997), "An Autoregressive Distributed Lag Modeling Approach to Cointegration Analysis" Trinity College, Cambridge, England Department of Applied Economics, University of Cambridge, England

Pesaran MH, Shin Y, Smith RJ (2001), "Bounds testing approaches to the analysis of level relationships", J. Applied Econometrics, 16: 289-326. 
Rakner L. \& Mulaisho D. (1999), "Aid and Reform in Zambia; Country Case Study", Michigan State University, USA

Ruttan VW (1989), "Why Foreign Economic Assistance?" Economic Development and Cultural Change, 37(2).

Staats SJ (2012)), "What Next for US Aid in Ethiopia?", US centre for Global Development

Sogge David (2002), "Who Is Aiding Whom?" Give and Take: What's the Matter with Foreign Aid? London \& New York: Zed Books.

Solow Robert M (1975) "Reswitching: Brief Comments," The Quarterly Journal of Economics, MIT Press, 89(1)

Tasew T (2011), "FOREIGN AID AND ECONOMIC GROWTH IN ETHIOPIA", MPRA Paper No. 33953

Tsikata tsidi M (1998), "Aid effectiveness: a survey of recent empirical literature", IMF paper on policy analysis and assessment.

Thirwall AP (1989), "Growth and Development: with Special reference to Developing Economies", McMillan Press, London.

Todaro M (1989), "Economic Development in the Third World"

White H (1993), Aid and Government: A Dynamic Model of Aid, Income and Fiscal Behaviour", J. Int. Develop. 5(3).

Tolessa Aboma (2001), "Foreign Aid Impact on Economic Growth in Ethiopia." Unpublished MSc Thesis, Addis Ababa University.

Wang P (2010), "On Endogenous Growth Theory", Department of Economics Washington University in St. Louis.
Weisskopf TE (1972.a), "The Impact of Foreign Capital Inflows on Domestic Savings in Underdeveloped Countries", J. Int. Econ. 2.

Williamson CR (2009), " Exploring the failure of foreign aid: The role of incentives and information”, Economics Department, Appalachian State University, Boone, NC, USA

William Easterly (1999), "The Ghost of Financing Gap Testing the Growth Model Used in the International Financial Institutions", J. Develop. Econ. 60(2): 423-438 December 1999

World Bank, World Development Report, Washington D.C., 1990.

World Bank (1998), "Assessing Aid: What Works, What Doesn't and Why", A World Bank Policy Research Report, Oxford University Press.

World Bank (2002), "Country policy and institutional assessment 2002 assessment questionnaire",http://siteresources.worldbank.org/IDA/Resources/C PIA2002.pdf

Yohannes B (2011), "the impact of foreign aid on economic growth in Ethiopia: accounting for transmission mechanisms" , A Thesis Submitted to the School of Graduate Studies of Addis Ababa University in Partial Fulfillment of the Requirements for the Degree of Master of Science in Economics.

How to cite this article: Prof Haile Girma (2015). The impact of foreign aid on economic growth: Emperical evidence from Ethiopia (1974-2011) using ARDL approach. J. Res. Econ. Int. Finance. 4(1):1-12 